\title{
References:
}

1. Krasniyk I., Kryvych M. Learning Foreign Languages in Context: Pros and Cons of Using Modern Computer Technologies. Modern Problems of Radio Engineering, Telecommunications and Computer Science, Proceedings of the 13th International Conference on TCSET 2016. Lviv. P. 838-842.

2. Educational and Scientific Centre for Distance Learning of the National Defense University of Ukraine named after Ivan Cherniakhovskyi. URL: http://adl.nuou.org.ua/distantsiyne-navchannya/

3. Language Training and Scientific Centre of National Academy of the Security Service of Ukraine. URL: http://academy.ssu.gov.ua/ua/structure/ Navchalno-naukoviy-centr-movno-pdgotovki.htm.

DOI https://doi.org/10.30525/978-9934-588-80-8-2.40

\section{КРИТЕРІЇ ДОБОРУ МОВНОГО МАТЕРІАЛУ ДЛЯ ФОРМУВАННЯ ЛАТИНСЬКОМОВНОЇ ТЕРМІНОЛОГІЧНОЇ КОМПЕТЕНТНОСТІ ІНОЗЕМНИХ СТУДЕНТІВ-МЕДИКІВ}

\author{
Лазер-Паньків О. В. \\ кандидат філологічних наук, дочент, \\ доцент кафедри загального мовознавства, \\ класичної філології та неоелліністики \\ Киівський національний університет імені Тараса Шевченка \\ Письменна Ю. О. \\ кандидат філологічних наук, \\ доцент кафедри загального мовознавства, \\ класичної філології та неоелліністики \\ Київський національний університет імені Тараса Шевченка \\ м. Київ, Украӥна \\ У навчальних програмах дисципліни «Latin Language and Medical \\ Terminology» [5;9] предметом вивчення визначено «увесь комплекс \\ греко-латинських лексичних одиниць, що $є$ основою для побудови \\ анатомічної, гістологічної, клінічної, фармацевтичної, хімічної, медико- \\ технічної термінології та граматичні принципи терміноутворення», а \\ кінцевою метою - «правильне і коректне використання греко-латин-
}


ських анатомо-гістологічних, фармацевтичних та клінічних термінів у практичній діяльності фахівця» [5; 9].

Враховуючи значний кількісний обсяг сучасної медичної термінології, іiі багатоаспектність та неоднорідність, а також практичне значення для майбутньої професійної діяльності, метою дослідження є визначення головних $\mathrm{i}$ другорядних критеріїв добору мовного (лексичного, граматичного та фонетичного) матеріалу для використання у навчальному процесі у межах курсу «Latin Language and Medical Terminology», що $\epsilon$ важливою передумовою ефективності формування латинськомовної термінологічної компетентності (ЛТК). Необхідно не лише чітко виділити лексичні одиниці іноземної мови та визначити їх кількість, а й систематизувати лексичний мінімум, який буде відповідати як вимогам робочої програми дисципліни й освітніх стандартів [11, с. 10], так і цілям курсу, статусу предмета та навчальній ситуації $[1$, с. 5-6].

У сучасній лінгводидактиці розроблена низка критеріїв добору мовного матеріалу для формування певного виду компетентностей

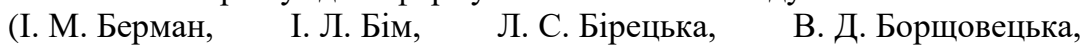
Б. А. Лапідус, . І. Липська, О. О. Миролюбов, К. О. Митрофанова, С. Ю. Ніколаєва, В. В Сафонова, Ю. О. Семенчук, О. М. Соловова, О. Б. Тарнопольський, В. С. Цетлін, О. М. Шамов та ін.). Аналіз та узагальнення науково-методичних досліджень, а також власний досвід викладання курсу «Latin Language and Medical Terminology» іноземним студентам-медикам дозволили виокремити основні критерії добору мовного матеріалу.

Обмеження за часом та кількістю кредитів, відведених на вивчення курсу «Latin Language and Medical Terminology», зумовлює і значне обмеження фактичної кількості термінологічних одиниць для освоєння протягом навчального періоду (особливо якщо враховувати той факт, що загальна кількість медичних термінів складає понад 200 тис. одиниць [4, с. 87]). За таких умов, на нашу думку, насамперед необхідно добирати найбільш часто уживані у сучасній медичній практиці лексику та терміноелементи (коефіцієнт повторюваності яких у джерелах відбору, за Ю. І. Пассовим, становить не нижче п'яти [12, с. 39]), тобто враховувати критерій частотності.

Критерій словотворчої $i$ стройової здатності є, на наше переконання, визначальним, адже саме словотворча і стройова здатність терміноелементів дозволяє сформувати потенційний словник студентівмедиків: знаючи певну кількість терміноелементів 3 високим словотвірним потенціалом, студенти зможуть утворювати та семантизувати на ї основі значну кількість похідних термінів. Як показало дослідження M. Yurtbaşı, «набір з 27 коренів, 32 префіксів, 23 суфіксів та розуміння, 154 
як їх використовувати, розкриє значення понад 100,000 англійських слів» $[6$, c. 50]. У медичній термінології цей показник ще вищий, окрім того, латина та грека складають унікальну базу, яка може бути використана для створення нового терміна» [3, с. 582].

Особливо важливим є критерій актуальності. Він передбачає використання у процесі формування ЛТК актуального мовного матеріалу, 3 урахуванням того факту, що медична термінологія становить відкриту динамічну систему, в якій певні терміни можуть 3 часом зникати або змінювати своє значення; водночас постійно відбувається формування нових термінологічних одиниць.

За критерісм професійної спрямованості, добору підлягають мовні одиниці, характерні для фахової мови. У цьому контексті особливої ваги набуває виокремлений К. Митрофановою інтеграиійний критерій, за яким добір навчального матеріалу повинен відбуватися на засадах «належності лексичних одиниць до різних профільних навчальних дисциплін» [11, с. 13]. При цьому важливо враховувати можливі предметні складнощі у процесі формування ЛТК інтегровано 3 фаховими знаннями [7, с. 12-18; 8, с. 82-85], оскільки курс «Latin Language and Medical Terminology» викладається протягом першого року навчання і несе важливе пропедевтичне навантаження.

Таким чином, пов'язаним із зазначеними критеріями вважаємо критерій відповідності навчального матеріалу рівню навченості та інтелектуального розвитку студентів: навчальний матеріал, з одного боку, повинен відповідати вимогам програми навчальної дисципліни, а 3 іншого - враховувати індивідуальні та психологічні особливості студентів, їх фонові знання та рівень володіння іноземною мовою, якою здійснюється процес навчання.

Критерій сполучуваності передбачає здатність лексичної одиниці поєднуватися 3 іншими одиницями у мовленні, тобто, високий коефіцієнт валентності слова в мовленні [10, с. 222]. За А. Н. Щукіним, чим більше можливостей у слова поєднуватися з іншими словами, тим воно цінніше для вивчення мови [13, с. 289].

Згідно $з$ критерієм ситуативності та тематичності, добору підлягають мовні одиниці, розподілені за змістовими модулями дисципліни і згруповані за лексико-граматичним та / або семантичним принципами.

За критерієм семантичної цінності, необхідно добирати, у першу чергу, мовні одиниці, які позначають важливі для майбутньої фахової діяльності поняття.

У процесі формування ЛТК студентів-іноземців медичних спеціальностей критерій урахування рідної мови не може бути застосований повною мірою, адже, фактично, ми можемо враховувати 
лише мову викладання, яка далеко не для всіх студентів є рідною. Водночас цей критерій можна розглядати як допоміжний, оскільки у процесі формування ЛТК важливим є компаративний підхід з акцентом на особливостях фонетичного та граматичного освоєння латинських термінів та терміноелементів сучасною англійською мовою.

Отже, основними серед зазначених критеріїв вважаємо професійну спрямованість та інтегративність, словотворчу і стройову здатність, актуальність, частотність та семантичну цінність, а критерії ситуативності та тематичності, сполучуваності та урахування рідної мови, відповідності навчального матеріалу рівню навченості та інтелектуального розвитку студентів - допоміжними. Застосування цих критеріїв дозволило здійснити добір навчального мовного матеріалу для розробки вправ на формування ЛТК у іноземних студентів медичних спеціальностей [2].

\section{Література:}

1. Alcina A. Teaching and learning of terminology: New strategies and methods. Terminology. 2009. № 15(1). P. 1-9.

2. Lazer-Pankiv O., Pysmenna I. Latin Language and Medical Terminology: A Practice and Reference Book for Students. Kyiv: Logos, 2019. 164 p.

3. Marečková E., Simon F., Červeny L. Latin as the language of medical terminology: Some remarks on its role and prospects. SWISS MED WKLY. 2002. 132. P. 581-587.

4. Wermuth M.-C., Verplaetse H. Medical terminology in the Western world: Current situation. Handbook of Terminology, Vol. 2: Terminology in the Arab world. 2019. P. 84-108.

5. Work program on discipline «Latin Language and Medical Terminology» for students (specialty 222 «Medicine» and 224 «Technologies of medical diagnostics and treatment») / Developer: O. V. Lazer- Pankiv. Kyiv, 2018. 18 p.

6. Yurtbaşı, M. Building English vocabulary through roots, prefixes and suffixes. Global Journal of Foreign Language Teaching. 2015. № 5(1). P. 44-51.

7. Бондарев М. Г. Формирование лингвистической компетенции в процессе обучения профессионально ориентированному чтению с помощью компьютерной программы. Известия Российского государственного педагогического университета им. А.И. Гериена. 2008. № 82 (2). C. 12-18.

8. Лазоренко Л. В. Навчання англомовного монологічного мовлення майбутніх математиків з використанням Веб-квесту : дис. ... канд. пед. наук: 13.00.02. Київ, 2016. 251 с. 
9. Латинська мова та медична термінологія: примірна програма навчальної дисципліни підготовки фахівців другого (магістерського) рівня вищої освіти спеціальності 222 «Медицина» / Розробники: О. Г. Кисельова, О. А. Ніколаєнко. Київ, 2016. 28 с.

10. Методика навчання іноземних мов і культур: теорія і практика : підручник / за заг. ред. С. Ю. Ніколаєвої. - Київ : Ленвіт, 2013. 590 с.

11. Митрофанова К. А. Обучение иноязычной лексике медицинской сферы студентов-медиков: автореф. дис. ... канд. пед. наук: спец. 13.00.02. Екатеринбург, 2010. 23 с.

12. Пассов Е. И. Коммуникативный метод обучения иноязычному говорению. М. : Просвещение, 1985. 208 с

13. Щукин А. Н. Обучение иностранным языкам: Теория и практика: Учебное пособие для преподавателей и студентов. М.: Филоматис, 2004. 416 c.

DOI https://doi.org/10.30525/978-9934-588-80-8-2.41

\title{
МОЖЛИВОСТІ ПРОЕКТНОЇ ТЕХНОЛОГІЇ НАВЧАННЯ У ПРОФЕСІЙНІЙ ПІДГОТОВЦІ МАЙБУТНІХ ФАХІВЦІВ
}

\author{
Науменко Н. В. \\ кандидат педагогічних наук, \\ старший викладач кафедри освітніх та інформаиійних технологій \\ Начіональний фармачевтичний університет \\ Козлов А. В. \\ старший викладач кафедри фізичного виховання \\ Харківський національний педагогічний університет \\ імені Г. С. Сковороди \\ м. Харків, Украӥна
}

Інноваційна діяльність у навчанні майбутніх фахівців має різні форми й потребує принципово нових механізмів взаємодії теорії і практики. Однією 3 ефективних є проєктна технологія навчання. Передумову впровадження проєктної технології навчання в практику освітньої діяльності кафедри становлять два основні мотиви: пошук методів, які давали б змогу представити освітній процес як організацію переважно самостійної роботи здобувачів освіти та прагнення розглядати освіту більш широко, ніж просто передачу певного обсягу знань. 